\title{
GSK3A wt Allele
}

National Cancer Institute

\section{Source}

National Cancer Institute. GSK3A wt Allele. NCI Thesaurus. Code C51206.

Human GSK3A wild-type allele is located in the vicinity of $19 q 13.2$ and is approximately 12 $\mathrm{kb}$ in length. This allele, which encodes glycogen synthase kinase-3 alpha protein, plays a role in the regulation of both glycogen synthesis and the Wnt/beta-catenin signaling pathway. 